\title{
Change in hardness, yield strength and UTS of welded joints produced in St37 grade steel
}

\author{
A.R. Bahman and E. Alialhosseini \\ Department of Mechanical Engineering, Islamic Azad University of Semnan Branch, Semnan, Iran \\ Young Researchers Club, Islamic Azad University of Semnan Branch, Semnan, Iran
}

bahman_alireza@yahoo.com; emad.mec@gmail.com

\begin{abstract}
St37 is one of low carbon steels which is widely used in different industries especially for fabrication the automobile chassis and bodies. The chemical composition of this grade steel is included carbon between 0.17 and 0.2 (\%wt) and due to low carbon, its weldability is appropriate. MAG equipment is one of the oldest arc welding processes which is used for joining many of metals and alloys in form of plate, sheet and pipe. Present work focuses on relationship between the robotic MAG welding variables and mechanical properties of St37 steel joints.
\end{abstract}

Keywords: MAG parameters; weld metal; mechanical properties.

\section{Introduction}

The history of gas metal arc welding has its industrial introduction in the late 1940's (Lincoln Electric Co., 1995). It is an arc welding process which incorporates the automatic feeding of a continuous, consumable electrode that is shielded by an externally supplied gas. While the equipment provides automatic self-regulation of the electrical characteristics of the arc and deposition rate, the only manual controls required by the welder for semiautomatic operation are gun positioning, guidance, and travel speed. The arc length and the current level are automatically maintained (Lincoln Electric Co., 1997). A sample of MAG welding installation has been shown in Fig. 1.

MAG welding involves large number of interdependent variables that can affect product quality, productivity and cost effectiveness (Kim et al., 2003). Many studies and researches have been made so far to

Fig. 1. A sample of automatic MAG welding installation (Lincoln Electric Co., 1997)

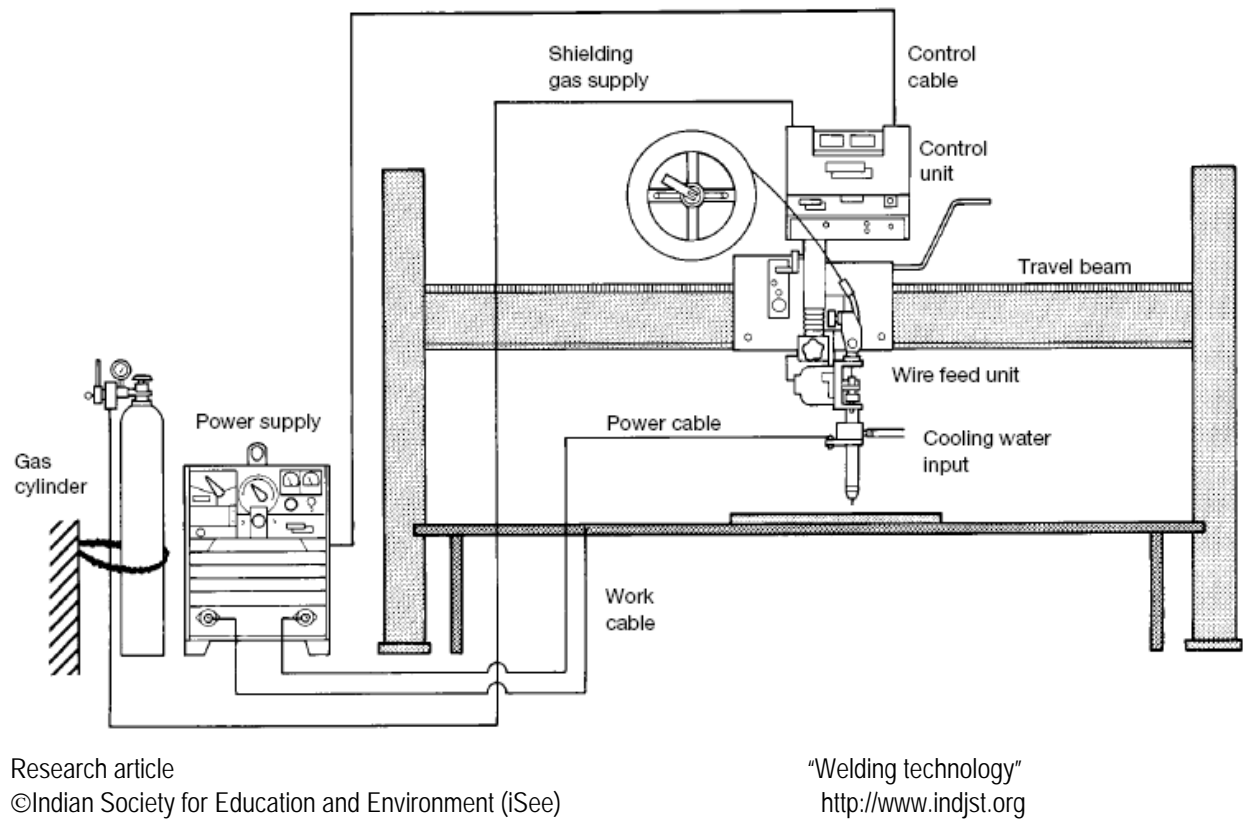

determine the effect of welding parameters on weld properties and quality. For example, Funderburk (1999) studied the effect of heat input on weld mechanical properties for SMA welding. The effects of friction welding parameters on mechanical properties of AA6056 joints were investigated by Cavaliere et al. (2006). Choi et al. (2005) researched on effect of current and voltage on strength of Lap-joints produced by $\mathrm{CO}_{2}$ welding process.

Table 1. Chemical compositions and mechanical properties of base material

\begin{tabular}{|l|c|c|c|c|}
\hline Element & $\mathrm{C}$ & $\mathrm{P}$ & $\mathrm{S}$ & $\mathrm{N}$ \\
\hline Wt $(\%)$ & 0.2 & 0.045 & 0.048 & 0.009 \\
\hline $\begin{array}{l}\text { Mechanical } \\
\text { property }\end{array}$ & $\sigma_{0.2}(\mathrm{MPa})$ & $\begin{array}{c}\text { UTS } \\
(\mathrm{MPa})\end{array}$ & $\begin{array}{c}\text { Elongation } \\
(\%)\end{array}$ & $\begin{array}{c}\text { Hardness } \\
(\mathrm{HB})\end{array}$ \\
\cline { 2 - 5 } & 238 & 370 & 24.5 & 155 \\
\hline
\end{tabular}

Also, Kacar \& Kokemli (2005) studied on influence of controlled atmosphere on the Mig-Mag arc weldment properties in low carbon steel. However, nearly there exists little information about relationship between MAG welding variables and mechanical properties of St 37 steel joints. The aim of this paper is investigation of arc voltage, welding current and welding speed effect on hardness, strength and UTS of weld metal.

\section{Materials and Methods}

Due to high industry importance and wide application, St37 steel plates having $25 \mathrm{~mm}$ thickness were selected as base material in this research. Chemical composition and mechanical properties of base material were shown in Table 1. In first, for reducing the possibility of defects formation in weld metal and preferment the weld quality, the A.R.Bahman \& E.Alialhosseini Indian J.Sci.Technol. 
rusts and other combinations were removed from plate's faces and after that, these parts were prepared for providing a $\mathrm{V}$ groove butt joint with $65^{\circ}$ groove angle.

SG2 (accordance with DIN Standard) having $1.2 \mathrm{~mm}$ diameter was selected as filling metal. Chemical composition of filling metal was shown in Table 2.

Table 2. Chemical compositions of filling metal
\begin{tabular}{|l|c|c|c|c|c|c|}
\hline Element & $\mathrm{C}$ & $\mathrm{Si}$ & $\mathrm{Mn}$ & $\mathrm{P}$ & $\mathrm{S}$ & $\mathrm{Cu}$ \\
\hline $\mathrm{Wt}(\%)$ & 0.11 & 0.95 & 1.85 & 0.022 & 0.02 & 0.05 \\
\hline
\end{tabular}

For reducing the distortion after the welding, the jig and fixture system was used for fixing the plates during the operations and welding process was performed by a CLOOS Model welding robot. The 18 weld passes were used to fill the space between bases plates. The fixed welding parameters during operations were shown in Table 3 and the welding variables were changed according to Table $4 a$.

Table 3. The fixed welding parameters during welding process

\begin{tabular}{|l|c|c|c|c|c|}
\hline Parameter & $\begin{array}{c}\text { Wire feeding } \\
\text { speed }\end{array}$ & $\begin{array}{c}\text { Gas flow } \\
\text { rate }\end{array}$ & $\begin{array}{c}\text { protective } \\
\text { gas }\end{array}$ & $\begin{array}{c}\text { gun } \\
\text { movement }\end{array}$ & $\begin{array}{c}\text { Gun } \\
\text { angle }\end{array}$ \\
\hline Amount/Type & $5.5 \mathrm{~m} / \mathrm{min}$ & $15 \mathrm{l} / \mathrm{min}$ & $\% \mathrm{CO}_{2}$ & $\begin{array}{c}\text { Steady } \\
\text { Movement }\end{array}$ & $75^{\circ}$ \\
\hline
\end{tabular}

Vol. 3 No. 12 (Dec 2010)

ISSN: 0974- 6846

\section{Results and Discussion}

The final results of this research were shown in Tables 5-7. In part 1, the welding current and welding speed were fixed on $135 \mathrm{~A}$ and $50 \mathrm{~cm} / \mathrm{min}$, respectively and effect of arc voltage on mechanical properties of weld metal was investigated.

In part 2, the arc voltage and welding speed were fixed on $24 \mathrm{~V}$ and $50 \mathrm{~cm} / \mathrm{min}$, respectively and effect of welding current on mechanical properties of weld metal was analyzed.

In part 3 , the arc voltage and welding current were fixed on $24 \mathrm{~V}$ and $135 \mathrm{~A}$, respectively and effect of welding speed on mechanical properties of weld metal was researched.

In according to Table 5, increasing the arc voltage between 20 and $28 \mathrm{~V}$, resulted in decreasing in hardness, yield strength and UTS of weld metal. Similarly, increasing the welding current between 115 and $155 \mathrm{~A}$ caused the decreasing in mechanical properties of weld metal. It was shown in Table 6 . In according to Table 7, effect of welding speed was against the previous variables. Increasing the welding speed between 40 and $60 \mathrm{~cm} / \mathrm{min}$ (in fixed arc voltage and welding current) caused the increasing the mechanical properties of weld metal.

After welding operation, tensile specimens were extracted from weld metal and prepared in accordance with ASME (section 9) guidelines (Fig. 2). The dimensions of specimen were tabulated in Table 4b.

Table 4a. Welding variables during welding process

\begin{tabular}{|l|c|c|c|c|c|}
\hline Arc voltage $(\mathrm{V})$ & 20 & 22 & 24 & 26 & 28 \\
\hline Welding current $(\mathrm{A})$ & 115 & 125 & 135 & 145 & 155 \\
\hline Welding speed $(\mathrm{cm} / \mathrm{min})$ & 40 & 45 & 50 & 55 & 60 \\
\hline
\end{tabular}

The tensile test was carried out in a $20 \mathrm{KN}$ capacity DARTEC testing machine, using a testing speed of 0.25 $\mathrm{mm} / \mathrm{s}$ for tensile test. Finally, brinel hardness test was performed on the welding samples surface.
These phenomenons can be related to metallurgical behavior of weld melt during solidification and chance of formation the defects in different conditions of welding. Increasing in arc voltage and welding current or reducing in welding speed increases the welding heat input. With increasing the input energy, grain growth in weld microstructure increases and grain boundaries are reduced in background. Reduction in grains boundaries as locks for movement of dislocations, increases possibility and amount of dislocations movement as line defects in structure. It will cause reduction in strength and hardness of weld metal. On the other hand, very high arc voltage and welding current or very low welding speed can increase the chance of defects formation such burn through in weld which affect on mechanical properties and quality of weld metal badly.
Table $4 b$. The dimension of tensile specimen in accordance with ASME guidelines

\begin{tabular}{|l|c|c|c|c|}
\hline Parameter & $\begin{array}{c}\text { G-Gage } \\
\text { length }\end{array}$ & D-Diameter & $\begin{array}{c}\text { r-Radius of } \\
\text { fillet }\end{array}$ & $\begin{array}{c}\text { A-Length of reduced } \\
\text { section }\end{array}$ \\
\hline $\begin{array}{l}\text { Amount } \\
(\mathrm{mm})\end{array}$ & 56 & 11.28 & 10 & 62 \\
\hline
\end{tabular}

Fig. 2. A schematic of tensile specimen

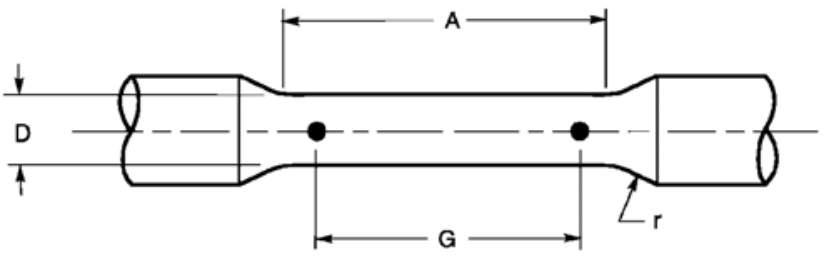

\section{Conclusions}

Increasing of the arc voltage and welding current increases the welding heat input: accordingly the chance of defects formation such burn through in weld metal also increases. Besides, the high welding current reduces the hardness, yield strength and UTS of weld metal. Whereas, increasing in welding speed decreases the welding heat input and chance of defects formation in weld metal. Thus, increasing the welding speed increases the hardness, yield strength and UTS of weld metal.
Research article

CIndian Society for Education and Environment (iSee)
"Welding technology" http://www.indjst.org Indian J.Sci.Technol. 
Table 5. Effect of arc voltage on mechanical properties of weld metal

\begin{tabular}{|c|c|c|c|}
\hline $\begin{array}{c}\text { Arc voltage } \\
(\mathrm{V})\end{array}$ & $\begin{array}{c}\text { Hardness } \\
(\mathrm{HB})\end{array}$ & $\begin{array}{c}\text { Yield strength } \\
(\mathrm{MPa})\end{array}$ & $\begin{array}{c}\text { UTS } \\
(\mathrm{MPa})\end{array}$ \\
\hline 20 & 188 & 271 & 390 \\
\hline 22 & 186 & 263 & 388 \\
\hline 24 & 182 & 260 & 383 \\
\hline 26 & 179 & 251 & 382 \\
\hline 28 & 173 & 249 & 378 \\
\hline
\end{tabular}

Table 6. Effect of welding current on mechanical properties of weld metal

\begin{tabular}{|c|c|c|c|}
\hline $\begin{array}{c}\text { Welding } \\
\text { current }(\mathrm{A})\end{array}$ & $\begin{array}{c}\text { Hardness } \\
(\mathrm{HB})\end{array}$ & $\begin{array}{c}\text { Yield strength } \\
(\mathrm{MPa})\end{array}$ & UTS (MPa) \\
\hline 115 & 178 & 267 & 387 \\
\hline 125 & 177 & 263 & 384 \\
\hline 135 & 174 & 257 & 382 \\
\hline 145 & 171 & 254 & 376 \\
\hline 155 & 169 & 253 & 373 \\
\hline
\end{tabular}

Table 7. Effect of welding speed on mechanical properties of weld metal

\begin{tabular}{|c|c|c|c|}
\hline $\begin{array}{c}\text { Welding speed } \\
(\mathrm{cm} / \mathrm{min})\end{array}$ & $\begin{array}{c}\text { Hardness } \\
(\mathrm{HB})\end{array}$ & $\begin{array}{c}\text { Yield strength } \\
(\mathrm{MPa})\end{array}$ & UTS (MPa) \\
\hline 40 & 167 & 248 & 372 \\
\hline 45 & 171 & 257 & 375 \\
\hline 50 & 180 & 264 & 385 \\
\hline 55 & 182 & 271 & 390 \\
\hline 60 & 187 & 277 & 398 \\
\hline
\end{tabular}

\section{References}

1. Cavaliere $P$, Campanile G, Panella F and Squillace A (2006) Effect of welding parameters on mechanical and microstructural properties of AA6056 joints produced by Friction Stir Welding. J. Material Processing Technology. 180, 263-270.

2. Choi J, Song J and Lim J (2005) Effects of current and voltage on welding strength of Lap-joint with $\mathrm{CO}_{2}$ welding process, Faculty of Mechanical \& Aerospace System Eng., Chonbuk Nat'I Univ., Jeonju , South Korea.

3. Funderburk SR (1999) Key Concepts in Welding Engineering, Welding Innovation, Vol. XVI, No. 1.

4. Kacar R, Kokemli K (2005) Effect of controlled atmosphere on the Mig-Mag arc weldment properties. J. Materials and Design. 26, 508-516.

5. Kim IS, Son JS, Kim IG, Kim JY, Kim OS (2003) A study on relationship between process variables and bead penetration for robotic $\mathrm{CO}_{2}$ arc welding. Journal of Materials Processing Technology. 136, 139-145.

6. Lincoln Electric CO. (1995) GMAW Welding Guide (for Carbon, Low Alloy, Stainless Steel and Aluminum), www.lincolnelectric.com.

7. Lincoln Electric CO. (1997) MIG/MAG Welding Guide (for Gas Metal Arc Welding), published by American Society for Metals, Third Edition. 